\title{
Using ancient DNA techniques to identify the origin of unprovenanced museum specimens, as illustrated by the identification of a $1^{\text {th }}$ century lion from Amsterdam
}

\author{
Ross Barnett ${ }^{1}$, Nobuyuki Yamaguchi ${ }^{2}$, Beth Shapiro ${ }^{1}$ and Vincent Nijman ${ }^{3}$ \\ ${ }^{1}$ Henry Wellcome Ancient Biomolecules Centre, University of Oxford, South Parks Road, Oxford, OX1 3PS UK, \\ ${ }^{2}$ Wildlife Conservation Research Unit, University of Oxford, Tubney House, Abingdon Road, Tubney, Abingdon, \\ OX13 5QL UK; ${ }^{3}$ Zoological Museum, University of Amsterdam, P.O. Box 94766, 1090 GT Amsterdam, The Nether- \\ lands,nijman@science.uva.nl
}

Key words: India, mitochondrial DNA, Panthera leo, skull morphology, South Africa

\begin{abstract}
In natural history collections throughout Europe, there are many old lion specimens of unknown origin. If these specimens can be shown to have originated from now-extinct populations their value would significantly increase, as would the value of the collections. Recently, a 200-year old mounted skeleton in the Zoological Museum Amsterdam has been identified as the extinct Cape lion Panthera leo melanochaita (Smith, 1842), based primarily on morphological information inferred from a painting of this specimen while it was still alive. To test this hypothesis, we used ancient DNA (aDNA) techniques to extract and sequence mitochondrial DNA (mtDNA) from this specimen, and compared the genetic results with previously published lion mtDNA sequences. Our results show that the specimen is not a Cape lion, but that it instead possesses the mtDNA haplotype of the Asiatic lions $P$. $l$. persica (Meyer, 1826) from India. This Indian origin hypothesis is further supported by an investigation of its cranial morphology. As the amount of genetic information available for lions increases, in particular data from across their historic distribution, the potential for aDNA techniques to identify the origins of previously unassigned museum specimens continues to grow.
\end{abstract}

\section{Contents}

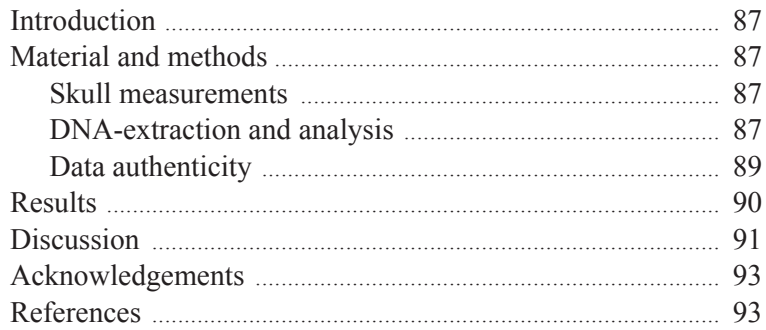

\section{Introduction}

The lion Panthera leo (Linnaeus, 1758) was once widespread throughout Africa and southwestern Eurasia, ranging from South Africa to Greece, and from Morocco to India (Nowell and Jackson, 1996). Most likely due to the expansion of human populations, lions disappeared from Greece by c. 2000 years ago, and from Palestine around the time of the Crusades c. $11^{\text {th }}$ $-12^{\text {th }}$ century. In the past 200 years, lions have disappeared from many parts of their former range, including the southern part of South Africa (by 1870), Turkey (1870), Tunisia (1891), Iraq (1918), Iran (1942), Morocco (1942) and Algeria (by 1960) (Yamaguchi and Haddane 2002; Patterson, 2004; K. Difalla, personal communication). Among the now extinct populations two are particularly famous: the North African Barbary lion P. l. leo (Linnaeus, 1758) and the South African Cape lion P. l. melanochaita (Smith, 1842) (Mazák 1975; Nowell and Jackson 1996). This range contraction has left fragmented populations in subSaharan Africa with an estimated total population of $\mathrm{c}$. $18,000-47,000$, and a single small population (c. 300) in India (Nowell and Jackson 1996; Bauer and Van der Merwe 2002; Chardonnet 2002).

Prior to their extinction, lions from North Africa, the Cape Province of South Africa, Iraq, and several other sites were imported into Europe, where it was common for lions to be exhibited in menageries and zoos (Guggisberg 1963; Hemmer 1978). After death, these specimens were deposited in natural history museums or private collections, where they remain until 
today. Unfortunately, many of these specimens are associated with little or no provenance information and this is particularly true for specimens dating to the $19^{\text {th }}$ century or earlier. As the recent range contraction has resulted in the loss of a substantial part of the lion's genetic diversity, these European specimens represent a significant, as yet untapped resource for the investigation of the evolution and historical distribution of lions. The recently "discovered" 200-year old lion specimen at the Zoological Museum of the University of Amsterdam, The Netherlands, is an important case in point (Van Bree, 1998). Previous analysis of this specimen has suggested that it is a Cape lion (Van Bree, 1998). This identification relied heavily on a painting made of this specimen while it was still alive by the Dutch artist P.G. van Os (1776-1839) (Van Bree and Welman, 1996; Van Bree, 1998; Reynaerts et al. 2006). However, osteological evidence presented in Van Bree (1998) contradicts this classification, as the measurements point out that this specimen possesses a large interorbital breadth (the smallest distance between the orbits) relative to the postorbital constriction (the smallest distance across the postorbital constriction), which is a typical characteristic of the North African - Indian lion skulls, rather than sub-Saharan lions (Hemmer 1974).

The ability to extract and analyse DNA sequences from old specimens provides a mechanism for resolving this debate. Once an organism dies, enzymatic processes begin to break down its DNA, however recent advances in molecular biological techniques have made it possible to amplify short fragments of ancient DNA (aDNA), normally mitochondrial DNA (mtDNA), from specimens up to 100,000 years old (Lindahl 1993). While lions were among the first felids whose phylogeny was investigated using molecular methods (O'Brien et al. 1987), genetic information has been lacking for this species from many parts of its natural range. Indeed, until very recently, published lion mtDNA sequences originated from only seven countries, making up less than half of its natural range: Botswana, India, Kenya, Namibia, South Africa, Tanzania, and Uganda (Janczewski et al. 1995; Burger et al. 2004; Dubach et al. 2005). Under such circumstances, even if mtDNA were successfully obtained from an unprovenanced specimen, it would be difficult to determine its origin. However, Barnett et al. (2006a, 2006b) amplified the HVR1 of mtDNA control region from 32 modern lion specimens representing most of the extant and historical natural range of lions. By comparing sequences obtained from unprovenanced museum specimens to the increased data set, it may be possible to assign the origins of these specimens with reasonable confidence.

In this paper, we re-examine the origin of the Amsterdam Cape lion using both aDNA techniques and skull morphology analysis. We also discuss the feasibility of using these techniques to identify previously unprovenanced museum specimens.

\section{Material and methods}

\section{Skull measurements}

The interorbital breadth and the postorbital constriction were measured on the Amsterdam "Cape" lion (ID number: ZMA710), and compared to those of lion skulls originated from India, and the southern part of the former Cape Province, South Africa (Table 1). Classification was based on museum labels, and we also included into the analysis a few old specimens labelled as Cape lion without any specific locations within South Africa (see Table 1). We did not follow the classification of the Cape lion suggested by Mazák (1975) which was recently contradicted (Barnett et al., 2006a, 2006b).

A skull was classified as subadult if cemento-enamel junctions of all canines were already visible above the alveoli of the cleaned skull and yet the basioccipitalbasisphenoid suture, and/or frontal suture, was still open. If those sutures were closed, a skull was classified adult. Measurements were carried out using a set of metal calipers to the nearest $0.02 \mathrm{~mm}$. The coefficient of variation for the interorbital breadth was $0.06 \%(n=$ 5 skulls with 3 repeats each), and that for the postorbital constriction was $0.09 \%(n=5$ skulls with 3 repeats each). Following Yamaguchi et al. (2004) we arbitrarily accept a less than $2 \%$ coefficient of variation as a cut-off line for reliability and consistency in measurements, which both met.

In addition to sexual size dimorphism that is common in the Felidae, it has been suggested that the skull morphological characteristics of captive lions differ from those of wild animals (Hollister, 1917). While both the painting and morphometric data suggest that the Amsterdam Cape lion is a male, the sex of the specimen was not explicitly given in the original record. Additionally, the specimen was known to have spent at least some time in captivity (Van Bree, 1998). We therefore included both male and female and both captive and wild individuals in our comparative data set. 
Table 1. Specimens of Cape lions and Asiatic lions that were analysed in this study. Identification was based on museum labels. There may be more captive specimens in addition to those that are clearly recorded as captive animals. The dates indicate either when the specimens were collected (e.g. collected in the field, presented to zoos, or died in zoos), or when the specimens were brought to the collections. Abbreviations and the details of the collections are as followed: $\mathrm{m}$ (male), $\mathrm{f}$ (female), a (adult), sa (subadult), London (Natural History Museum, London, UK), Oxford (Natural History Museum, University of Oxford, Oxford, UK), Paris (National Museum of Natural History, Paris, France), Leiden (National Natural History Museum, Leiden, The Netherlands), Amsterdam (Zoological Museum, Amsterdam University, Amsterdam, The Netherlands), Stockholm (Swedish Museum of Natural History, Stockholm, Sweden), Cape Town (South African Museum, Cape Town, South Africa), KWT (Amathole Museum, King William's Town, South Africa), PE (Port Elizabeth Museum Complex, Port Elizabeth, South Africa), and Bulawayo (Natural History Museum, Bulawayo, Zimbabwe). "Cape" is used here as the former Cape Province, South Africa, which consists of the current Eastern Cape, Western Cape, and Northern Cape provinces.

\begin{tabular}{|c|c|c|c|}
\hline Collection (ID number) & Sex/age & Date & Recorded origin \\
\hline \multicolumn{4}{|l|}{ P. l. melanochaita } \\
\hline 1 KWT (15904) & $\mathrm{m} / \mathrm{a}$ & 1940 & Welcomewood, King William's Town, Cape \\
\hline 2 Bulawayo (61463) & $\mathrm{m} / \mathrm{a}$ & 1966 & Port Elizabeth, Cape \\
\hline 3 Cape Town (33425) & $\mathrm{m} / \mathrm{a}$ & 1938 & Studtis, Willowmore, Cape \\
\hline 4 London $(1918.5 .23 .2)$ & $\mathrm{m} / \mathrm{a}$ & c. 1843 ? & South Africa (near Colesberg, Cape?) \\
\hline 5 London $(1936.5 .26 .6)$ & $\mathrm{m} / \mathrm{a}$ & 1848 & Cape Town (near Colesberg, Cape?) \\
\hline 6 Stockholm (A58/3712) & $\mathrm{m} / \mathrm{a}$ & 1874 & South Africa \\
\hline 7 Stockholm (A59/1310) & $\mathrm{m} / \mathrm{a}$ & 1845 & Caffraria interior, Cape \\
\hline 8 KWT (19150) & $\mathrm{m} / \mathrm{sa}$ & 1962 & Caledon district, Betty's Bay, Cape \\
\hline 9 PE $(1468 / 62)$ & $\mathrm{m} / \mathrm{sa}$ & 1952 & Tonderskraal, Murraysburg, Cape \\
\hline 10 Paris (A-1838) & $\mathrm{m} / \mathrm{sa}$ & & Cape (captive animal) \\
\hline 11 Leiden (Cat-i) & $\mathrm{m} / \mathrm{sa}$ & 1860 & Cape \\
\hline 12 Leiden (Cat-k) & $\mathrm{m} / \mathrm{sa}$ & 1860 & Cape \\
\hline 13 Oxford (14181) & $\mathrm{m} / \mathrm{sa}$ & 1876 & Cape \\
\hline 14 Cape Town (7529) & $\mathrm{f} / \mathrm{a}$ & & Bergplaats, Rooihoogte, Beaufort West, Cape \\
\hline 15 London (1846.7.2.6) & f/a & & South Africa (captive animal?) \\
\hline \multicolumn{4}{|l|}{ P. l. persica } \\
\hline 16 London (1930.6.6.1) & $\mathrm{m} / \mathrm{a}$ & & Amreli district, Kathiawar, Gujarat, India \\
\hline 17 London (1931.1.5.1) & $\mathrm{m} / \mathrm{a}$ & & Kathiawar, Gujarat, India \\
\hline 18 London (1931.1.5.2) & $\mathrm{m} / \mathrm{a}$ & & Gir Forest, Kathiawar, Gujarat, India \\
\hline 19 London (1931.1.13.1) & $\mathrm{m} / \mathrm{a}$ & & Gir Forest, Kathiawar, Gujarat, India \\
\hline 20 Paris $(1873-556)$ & $\mathrm{m} / \mathrm{a}$ & 1874 & India \\
\hline 21 London (1857.2.24.1) & $\mathrm{f} / \mathrm{a}$ & 1854 & Gujarat, India (captive animal) \\
\hline 22 London (1931.4.13.2) & $\mathrm{f} / \mathrm{a}$ & & Gir Forest, Kathiawar, Gujarat, India \\
\hline 23 London (1945.136) & $\mathrm{f} / \mathrm{a}$ & 1945 & Kathiawar, Gujarat, India (captive animal) \\
\hline 24 Paris $(\mathrm{A}-1884)$ & $\mathrm{f} / \mathrm{a}$ & 1838 & India (captive animal?) \\
\hline 25 Paris (I-1460) & $\mathrm{f} / \mathrm{a}$ & 1843 & Bengal (captive animal?) \\
\hline 26 Paris $(1962-2872)$ & $f / a$ & & India \\
\hline 27 Oxford (14174) & $\mathrm{f} / \mathrm{a}$ & 1876 & India \\
\hline
\end{tabular}

\section{DNA extraction and analysis}

Samples of a mounted lion skeleton (ID number: ZMA710) kept in the Zoological Museum of the University of Amsterdam, The Netherlands, which was identified as the Cape lion (Van Bree, 1998), were obtained twice independently. First sampling was carried out in 1999 (Sample-1), and the second in 2006 (Sample-2). Small pieces of dried tissue (up to c. $10 \times$ $10 \times 5 \mathrm{~mm}$ ) attached to the mounted skeleton were removed for DNA analysis. Laboratory procedures were performed according to strict aDNA criteria fol- lowing Barnett et al. (2006a).

For both samples, a 130 base pair (bp) fragment of the mitochondrial hypervariable region was amplified as described in Barnett et al (2006a). This fragment was chosen as it is known to contain nucletotide polymorphisms that make it possible to discriminate between lions originating from different populations.

\section{Data authenticity}

Sample-1 was extracted and amplified in July 2005 as part of a large-scale investigation of the lion phylogenet- 
ics and evolution (for details see Barnett et al. 2006a, 2006b). Sample-2 was analysed in May 2006 following the procedure outlined in Barnett et al. (2006a). Multiple PCR and extraction controls were also carried out for Sample-2, which was amplified and cloned twice. All replications produced identical sequences. Sample1 and Sample-2 produced identical sequences, and the sequences were deposited in GenBank (Accession number EF517785).

The Felidae are known to contain macrosatellites (Numts) resulting from nuclear translocation of the mtDNA (Lopez et al., 1997; Cracraft et al., 1998). Previous studies of Panthera mtDNA control region have revealed a Numt significantly divergent from any mitochondrial copy (Jae-Heup et al., 2001). Cloning of PCR products from Sample-2 did not find any sequences with homology to the Panthera Numt.
The cloned mtDNA sequences obtained were then aligned with those of other lions (Barnett et al. 2006a, 2006b) using Se-Al (Rambaut, 1996) and visually checked.

\section{Results}

The origin-known Asiatic lions from India were clearly separated from the origin-known Cape lions based on the ratio between interorbital breadth and postorbital constriction (Fig. 1). The Amsterdam specimen was placed very close to the range for the examined Indian lions, well outside of the range for the examined Cape lions (Fig. 1).

Approximately 130-bp of the mitochondrial DNA (HVR1) was amplified from both Sample-1 and -2, and

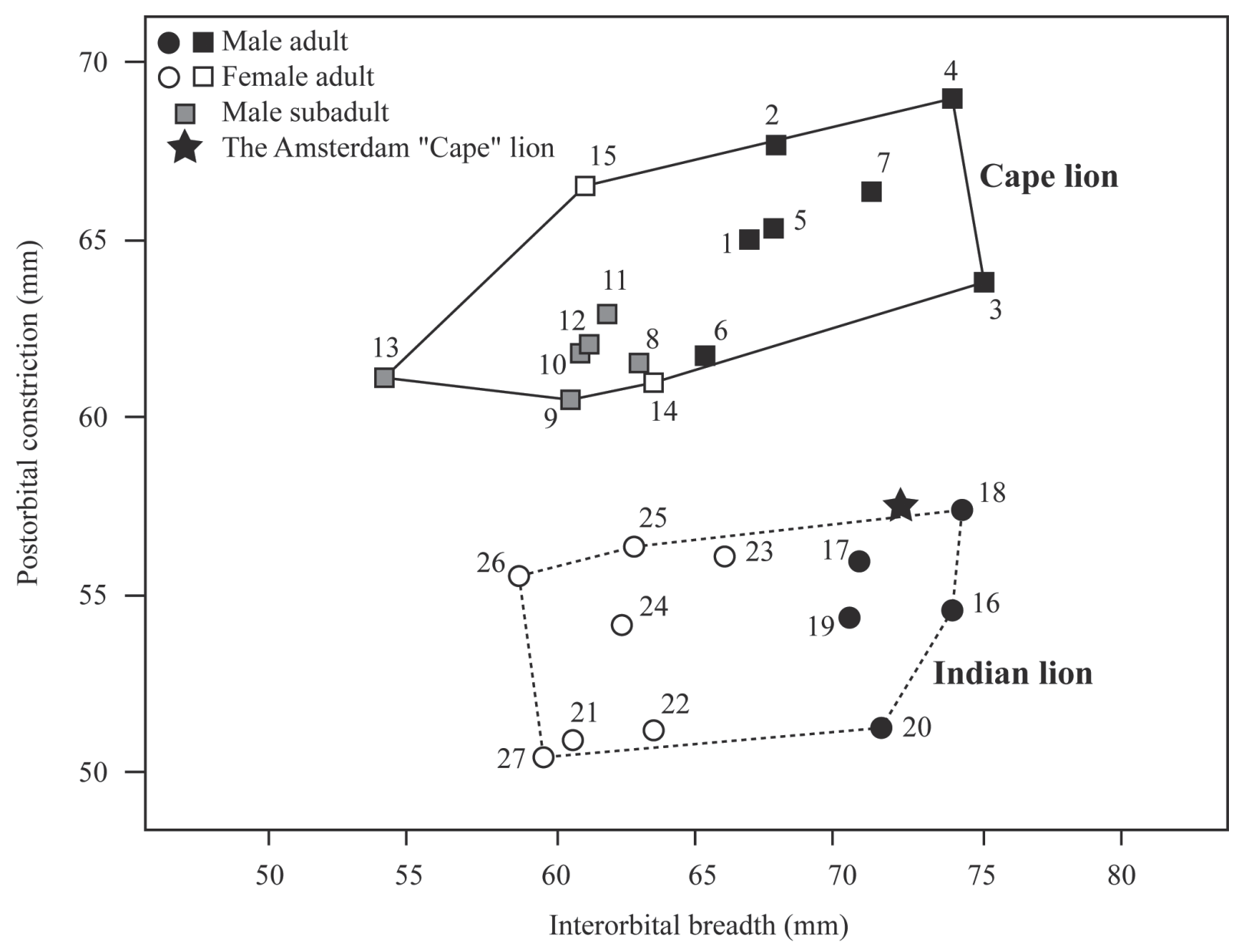

Fig. 1. Scatterplot of Postorbital constriction against Interorbital breath of Indian lions Panthera leo persica and Cape lions $P$. l. melanochaita as well as the Amsterdam "Cape" lion, showing a clear distinction between the two subspecies. The Amsterdam lion clusters with the Indian lions. Numbers are corresponding to those in Table 1. 
produced identical sequences. Comparison of this sequence with previously published data revealed them to be identical to sequences of the Asiatic lion from India (Fig. 2).

\section{Discussion}

Our results based on both molecular and morphometric data, suggest that the specimen in question likely belongs to the Indian population of the Asiatic lion rather than that of the Cape lion, contradicting the previous identification by Van Bree (1998).

Van Bree (1998) stated "...till the middle of the $19^{\text {th }}$ century the only lions arriving in Europe either came from North Africa or from the Cape." He gives no source for this assertion, but if this were true, the focal specimen, which died in 1809 (Van Bree, 1998), would most likely not have been an Asiatic lion. However, natural history books published during the $18^{\text {th }}-$ early $19^{\text {th }}$ centuries suggest that, while they were not common, Asiatic lions were imported into Europe before the middle of the $19^{\text {th }}$ century (Buffon and Daubenton, 1761; Bennett, 1829; Jardine, 1834). Because the Cape Colony, South Africa, was under Dutch rule from 1652 until 1806 , it is possible that some lions imported to The Netherlands may have been Cape lions, and indeed Van Bree (1998), followed by Reynaerts et al. (2006), used this line of reasoning to corroborate his conclusions. However, by the end of the $18^{\text {th }}$ century, the Dutch had established colonies and trading posts within or bordering the range of the Asiatic lion in India, therefore it is also possible that lions may have been exported to The Netherlands from these colonies. The most relevant of the Dutch colonies in this region were a number of posts in Suratte, northwestern India, opposite to the Kathiawar Peninsula, where the only remaining Indian lion population exists today, and those in Coromandel on the east coast of India (Israel, 1990). Additionally, exotic animals were brought into and moved around

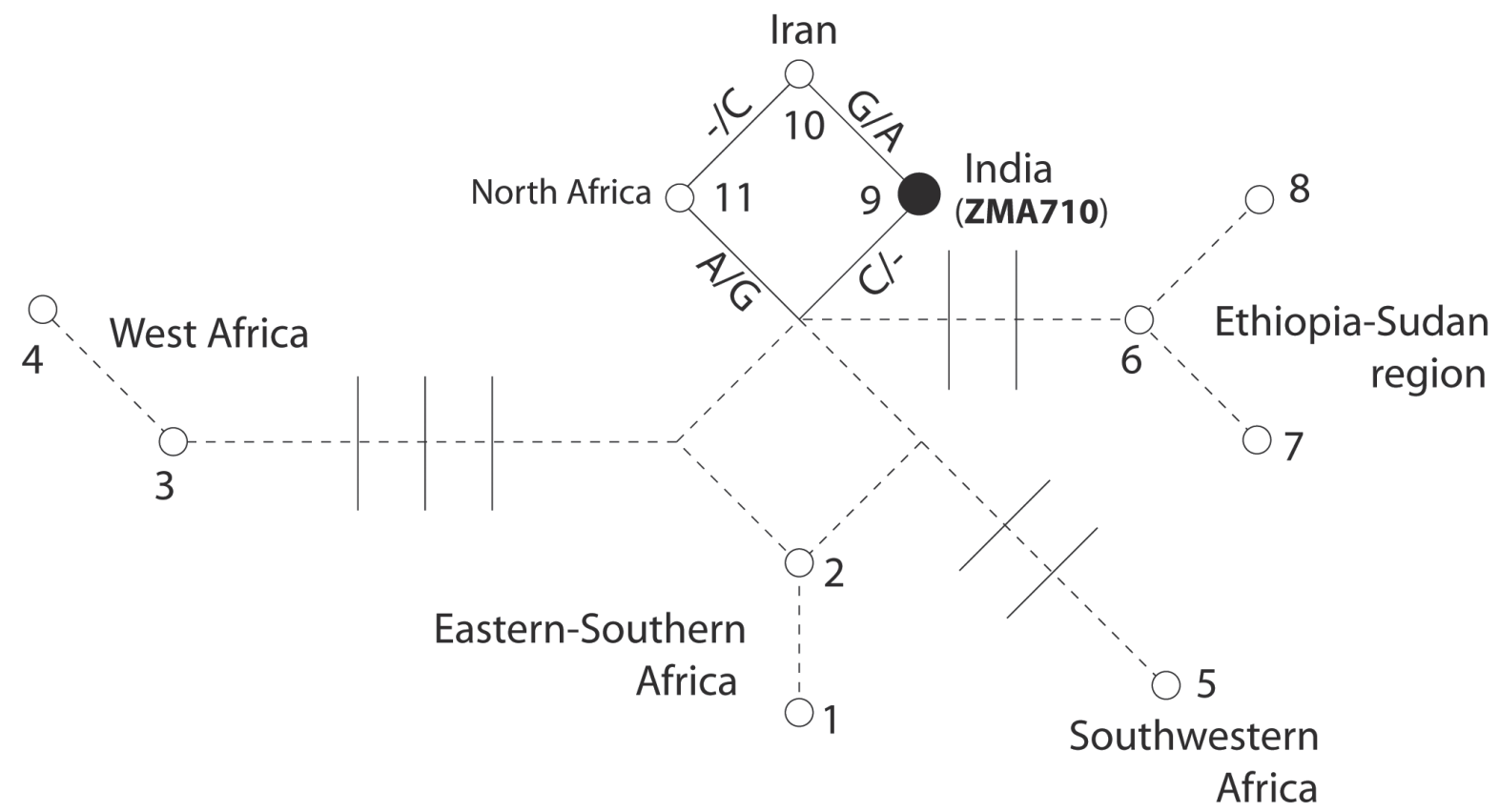

Fig. 2. Median-joining network of lion HVR1 constructed from the resulting sequences using Network v4.1.0.3 (Bandelt et al., 1999). The figure is modified from Barnett et al. $(2006 \mathrm{a}, \mathrm{b})$. The length of each connecting line is proportional to the distance between haplotypes (defined as the number of mutations). A point of intersection without an associated circle denotes a hypothetical common ancestor. Dashed lines lead to sub-Saharan African haplotypes whilst North African - Asian haplotypes are connected by solid lines with associated mutations identified. The large black circle indicates the position of the Amsterdam lion (ID number: ZMA710) sharing an identical haplotype with Asiatic lions from India. Numbers next to circles correspond to different mtDNA haplotypes identified in Barnett et al. (2006a, b). In brief, they are as follows. Haplotype-1 was found in lions originated from Tanzania $(N=1), 2$ (Kenya, Tanzania, Democratic Republic of Congo, Zambia, Namibia, South Africa, $N=9$ ), 3 (Burkina Faso, $N=1$ ), 4 (Senegal, $N=2$ ), 5 (Zimbabwe, Botswana, Gabon, Namibia, South Africa, $N=6$ ), 6 (Ethiopia, Central African Republic, $N=3$ ), 7 (Democratic Republic of Congo, $N=1), 8($ Sudan, $N=$ 1), 9 (India, $N=2$ ), 10 (Iran, $N=2$ ), and 11 (Algeria, Tunisia, "North Africa", "Barbary", $N=4$ ). The Cape lion originated from King William's Town, South Africa (1 in Table 1) possesses haplotype-5. 

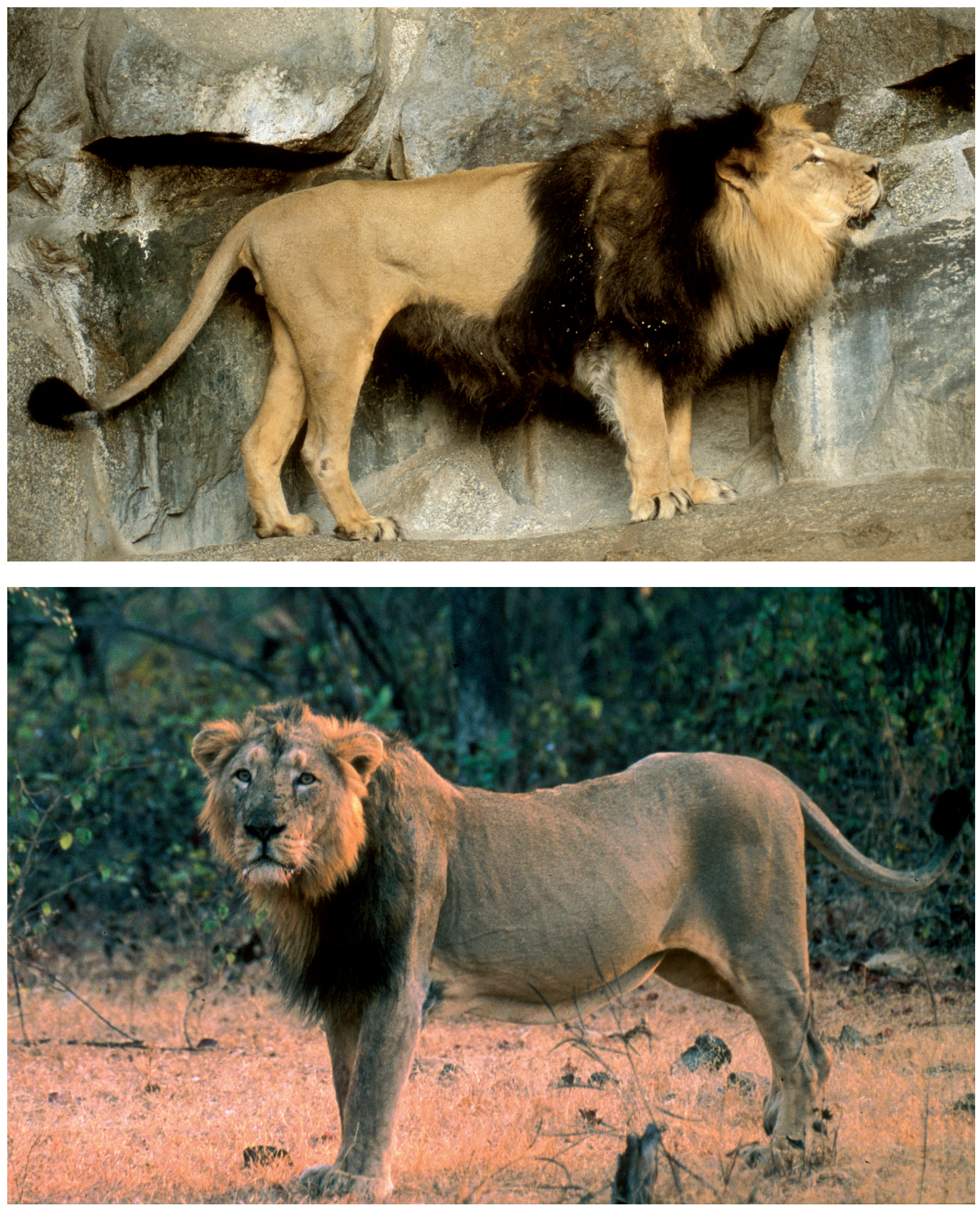

Fig. 3. Picture of a wild (bottom) and a captive (top) male Indian lion Panthera leo persica, showing an example of phenotypic plasticity of the lion's mane. The photo of the wild lion was taken in the Gir Lion Sanctuary, north-west India, and that of the captive in Berlin Zoo, Germany (photos: N. Yamaguchi). 
Europe ever since the Roman period, with a possible exception of the period between $c$. the $8^{\text {th }}$ and $13^{\text {th }}$ centuries (Baratay and Hardouin-Fugier, 2002). In this context, even if the Dutch had not possessed any trading post in India, Asiatic lions may have been imported occasionally to The Netherlands.

Early authors believed that apparently distinct external morphological characters particular to some lion populations, for example the male's huge dark mane that extends behind the shoulders and covers the ventral part of the body in Barbary and Cape lions, could be used to identify lions as belonging to particular populations (Harper, 1945; Mazák, 1970, 1975). The identification of the Amsterdam specimen depended on the animal's huge dark mane as it was depicted in a painting of the animal when still alive (Van Bree, 1998). However, it is now known that size and colour of a lion's mane are influenced by various factors, including ambient temperature, animal's age and testosterone level (Kays and Patterson, 2002; West and Packer, 2002; Patterson et al., 2006). In particular, the Asiatic lion from India, which is characterised by a very small mane in its natural habitat, grows an enormous mane with its greater part being dark or even black, which extends behind the shoulders and covers the belly, in European zoos (Yamaguchi and Haddane, 2002; Yamaguchi unpublished, see Fig. 3). Therefore, a heavy mane developed in a cooler place (e.g. menageries and zoos in Europe) would be an inappropriate marker (in comparison to molecular markers) for assigning the individuals to particular populations.

The mtDNA control region (HVR1) has proven to be useful in constructing the general intraspecific lion phylogeny, and has been used to identify molecular markers that are capable of discriminating between dozens of lion populations throughout the species range (Barnett et al. 2006a, 2006b). Importantly, it appears that only a small fragment of the HVR1 (c. 130 bp) is required for population-level identification: while genetic variation among lion mtDNA is low, the HVR1 is the most variable marker known, and contains as many informative sites as much longer stretches of sequence in other regions (Barnett et al. 2006b). This suggests that DNA identification of old museum specimens is not only realistic, but also quick and costeffective. The most significant difficulty associated with this approach is that mtDNA, which is commonly used for aDNA analysis, is inherited strictly from the mother, and therefore can only provide insight into the maternal lineage of the specimen investigated. Techniques in aDNA analysis are advancing rapidly, how- ever, and it may soon be possible to isolate paternalspecific DNA sequences (e.g. Y-chromosome DNA) from large numbers of specimens, which will enable identification of both the maternal and paternal lineages. Such advances will provide significant insights into the historical phylogenetics and behaviour of the lion (e.g. sexual difference in their dispersal pattern), in addition to making possible the accurate assignation geographic origin to poorly documented museum specimens. In spite of the difficulties associated with aDNA research, it would be worthwhile for museums to re-examine old lion specimens of unknown origin. Newly "discovered" specimens originated from extinct lion populations would increase our understanding of these lost populations, which in turn would help us understand the true diversity (e.g. morphological, anatomical, and genetic) of the lion. In addition to those science- and conservation-oriented interests, specimens from extinct lion populations would increase in value, and underscore the significance of museum collections.

\section{Acknowledgements}

We thank D. Hills, P. Jenkins, G. Watson, D. Drinkrow, W. Cotteril, J. Cuisin, B. Fernholm, O. Grönwall, F. Kigozi, A. Kitchener, F. Renoud, D. Robineau, C. Smeenk, M. Tranier, and L. Werdelin for their support for skull measurements, and P.J.H. Van Bree for his support concerning the access to the Amsterdam "Cape" lion specimen. We thank the reviewers for constructive comments.

\section{References}

Bandelt H-J, Forster P, Röhl A. 1999. Median-joining networks for inferring intraspecific phylogenies. Molecular Biology and Evolution 16: 37-48.

Barnett R, Yamaguchi N, Barnes I, Cooper A. 2006a. Lost population and preserving genetic diversity in the lion Panthera leo: implications for its ex situ conservation. Conservation Genetics 7: 507-514.

Barnett R, Yamaguchi N, Barnes I, Cooper A. 2006b. The origin, current diversity, and future conservation of the modern lion (Panthera leo). Proceedings of the Royal Society, series B: Biological Science 273: 2119-2125.

Baratay E, Hardouin-Fugier, E. 2002. Zoo: A history of zoological gardens in the West. London: Reaktion Books.

Bauer H, van der Merwe S. 2002. The African Lion Database. Cat News 36, 41-53.

Bennett ET. 1829. The Tower Menagerie: Comprising the natural history of the animals contained in that establishment, with anaecdotes of their characters and history. London: R. Jennings. 
Buffon GLL, Daubenton LJM. 1761. Histoire naturelle, générale et particuliére avec la discription tome neuvième. Paris: De L'Imprimerie Royale.

Burger J, Rosendahl W, Loreille O, Hemmer H, Eriksson T, Götherström A, Hiller J, Collins MJ, Wess T, Alt KW. 2004. Molecular phylogeny of the extinct cave lion Panthera leo spelaea. Molecular Phylogeny and Evolution 30: 841-849.

Chardonnet P. 2002. Conservation of the African lion: Contribution to a Status Survey. Paris: International Foundation for the Conservation of Wildlife. France and Conservation Force, USA.

Cracraft J, Feinstein J, Vaughn J, Helm-Bychowski K. 1998. Sorting out tigers (Panthera tigris): mitochondrial sequences, nuclear inserts, systematics, and conservation genetics. Animal Conservation 1: 139-150.

Dubach J, Patterson BD, Briggs MB, Venzke K, Flamand J, Stander P, Scheepers L, Kays RW. 2005 Molecular genetic variation across the southern and eastern geographic ranges of the African lion, Panthera leo. Conservation Genetics 6: $15-24$.

Guggisberg CAW. 1963. Simba. Philadelphia: Chilton Books.

Harper F. 1945. Extinct and vanishing mammals of the Old World. New York: American Committee for International Wild Life Protection New York Zoological Park.

Hemmer H. 1974. Untersuchungen zur Stammesgeschichte der Pantherkatzen (Pantherinae). teil III. Zur Artgeschichte des Löwen Panthera (Panthera) leo (Linnaeus 1758). Veröffentlichungen der Zoologischen Staatssammlung (München) 17: 167-280.

Hemmer H. 1978. Grundlagen und der Zeitiger stand des Zuchtprogrammes zur Rückerhaltung des Berberlöwen. Pp 65-73 in Seifert S, Muller P, editors. International tiger studbook. Leipzig: Zoological Garden Leipzig.

Hollister N. 1917. Some effects of environment and habit on captive lions. Proceedings of the US National Museum 53: 177-193.

Israel JI. 1990. Dutch primacy in World trade, 1585-1740. Oxford: Oxford University Press.

Jae-Heup K, Eizirik E, O’Brien SJ, Johnson WE. 2001. Structure and patterns of sequence variation in the mitochondrial DNA control region of the great cats. Mitochondrion 1: 279-292.

Jardine W. 1834: The naturalist's library Vol. II the natural history of Felinae. Edinburgh: W. H. Lizars, and Stirling and Kenny.

Janczewski DN, Modi WS, Stephens JC, O’Brien SJ. 1995. Molecular evolution of mitochondrial 12S RNA and cytochrome $\mathrm{b}$ sequences in the Pantherine lineage of Felidae. Molecular Biology and. Evolution 12: 690-707.

Kays RW, Patterson BD. 2002. Mane variation in African lions and its social correlates. Canadian Journal of Zoology 80: 471-478.
Lindahl, T. 1993. Instability and decay of the primary structure of DNA. Nature 362: 709-715.

Lopez JV, Culver M, Stephens JC, Johnson WE, O'Brien SJ. 1997. Rates of nuclear and cytoplasmic mitochondrial DNA sequence in mammals. Molecular Ecology and Evolution 14: 277-286.

Mazák V. 1970. The Barbary lion, Panthera leo leo, (Linnaeus 1758): some systematic notes, and an interim list of the specimens preserved in European museums. Zeitschrift für Säugetierkunde 35: 34-45.

Mazák V. 1975. Notes on the black-maned lion of the Cape, Panthera leo melanochaita (Ch. H. Smith, 1842) and a revisited list of the preserved specimens. Verhandelingen van de Koninklijke Nederlandse Akademie van Wetenchappen (Natuurkunde) 64: 1-44.

Nowell K, Jackson P. 1996. Wild cats: status survey and conservation action plan. Gland: IUCN.

O'Brien SJ, Martenson JS, Packer C, Herbst L, De Vos V, Joslin P, Ott-Joslin J, Wildt DE, Bush M. 1987. Biochemical genetic variation in geographic isolates of African and Asiatic lions. National Geogaphic Research 3: 114-124.

Patterson BD. 2004. The Lions of Tsavo. New York: McGrawHill.

Patterson BD, Kays RW, Kasiki SM, Sebestyen VM. 2006. Developmental effects of climate on the lion's mane (Panthera leo). Journal of Mammalogy 87:193-200.

Rambaut A. 1996. Se-Al: Sequence Alignment Editor. Available at http://evolve.zoo.ox.ac.uk/.

Reynaerts J, van de Laar M, van Putten H. 2006. The king, the painter and the lion. Amsterdam: Rijksmuseum and Nieuw Amsterdam Publishers.

Van Bree PJH. 1998. On a mounted skeleton of apparently the extinct Cape lion, Panthera leo melanochaita (Ch. H. Smith, 1842). Contributions to Zoology 68: 67-71.

Van Bree PJH, Welman W. 1996. Een leeuw van Lodewijk Napoleon. Amstelodanum 83: 179-184.

West PM, Packer C. 2002. Sexual selection, temperature, and the lion's mane. Science 297: 1339-1343.

Yamaguchi N, Driscoll CA, Kitchener AC, Ward JM, Macdonald DW. 2004. Craniological differentiation amongst the European wildcat (Felis silvestris silvestris), the African wildcat (F. s. lybica) and the Asian wildcat (F. s. ornata): implications for their evolution and conservation. Biological Journal of the Linnean Society 83: 47-64.

Yamaguchi N, Haddane B. 2002. The North African Barbary lion and the Atlas Lion Project. International Zoo News 49: 465481 .

Received: 22 August 2006

Accepted: 23 March 2007 